\title{
De wet als zinsbegoochelingstoestel : over de kwaliteit van wetgeving
}

Citation for published version (APA):

Veerman, G. J. (2004). De wet als zinsbegoochelingstoestel : over de kwaliteit van wetgeving. Universiteit Maastricht. https://doi.org/10.26481/spe.20040625gv

Document status and date:

Published: 25/06/2004

DOI:

$10.26481 /$ spe.20040625gv

Document Version:

Publisher's PDF, also known as Version of record

\section{Please check the document version of this publication:}

- A submitted manuscript is the version of the article upon submission and before peer-review. There can be important differences between the submitted version and the official published version of record.

People interested in the research are advised to contact the author for the final version of the publication, or visit the DOI to the publisher's website.

- The final author version and the galley proof are versions of the publication after peer review.

- The final published version features the final layout of the paper including the volume, issue and page numbers.

Link to publication

\footnotetext{
General rights rights.

- You may freely distribute the URL identifying the publication in the public portal. please follow below link for the End User Agreement:

www.umlib.nl/taverne-license

Take down policy

If you believe that this document breaches copyright please contact us at:

repository@maastrichtuniversity.nl

providing details and we will investigate your claim.
}

Copyright and moral rights for the publications made accessible in the public portal are retained by the authors and/or other copyright owners and it is a condition of accessing publications that users recognise and abide by the legal requirements associated with these

- Users may download and print one copy of any publication from the public portal for the purpose of private study or research.

- You may not further distribute the material or use it for any profit-making activity or commercial gain

If the publication is distributed under the terms of Article $25 \mathrm{fa}$ of the Dutch Copyright Act, indicated by the "Taverne" license above, 
De wet als zinsbegoochelingstoestel over de kwaliteit van wetgeving 


\section{Colofon}

Basisontwerp en realisatie: Unigraphic, Universiteit Maastricht

Omslag-foto: Ariane James

Object: "de uitvinding" van Mark Bischof

ISBN 90-5681-199-1

NUR 820

Alle rechten voorbehouden. Niets uit deze uitgave mag worden verveelvoudigd, opgeslagen in een geautomatiseerd gegevensbestand of openbaar gemaakt, zonder voorafgaande schriftelijke toestemming van de auteur of uitgever. 


\section{De wet als zinsbegoochelingstoestel}

over de kwaliteit van wetgeving

\section{Rede}

uitgesproken bij de aanvaarding van het ambt van hoogleraar in het recht, in het bijzonder de wetgeving en wetgevingskwaliteit, aan de Universiteit Maastricht op vrijdag 25 juni 2004

mr.dr. G.J. Veerman 



\section{Inhoudsopgave}

$\begin{array}{ll}\text { 1. Inleiding } & 7\end{array}$

2. Uiteenlopende problemen 9

2.1 Verschillen in de tijd 9

2.2 De ambiguïteit van wetgeving 9

2.3 Problemen op macro-, meso- en microniveau 11

3. Over de kwaliteit van wetgeving 13

3.1 Het begrip 'kwaliteit' 13

3.2 De kwaliteit van wetten $\quad 15$

3.3 De makers van wetten $\quad 18$

3.4 De klanten: de scheiding tussen de wet in wording
en de wet in werking

3.5 Perfect bestaat niet $\quad 23$

4. De ellende van de wet is de ellende van het beleid 24

4.1 Wetgevingskwaliteit als beleidsprobleem 24

4.2 Falende kennis, falend beleid $\quad 25$

4.3 De invloed van de politieke rationaliteit 28

5. De barrière van het wetgevingskwaliteitsbeleid 32

5.1 Het wetgevingskwaliteitsbeleid 32

5.2 Waarom die barrière niet volmaakt werkt 33

6. Kwaliteitsimpulsen en onderzoek 36

6.1 De wet als zinsbegoochelingstoestel 36

6.2 Kwaliteitsimpulsen en onderzoek 37

7. Dankwoord 41 

Mijnheer de rector magnificus,

Geliefde en gewaardeerde toehoorders,

\section{Inleiding}

Er zijn de nodige ongeruste geluiden over de kwaliteit van wetgeving.

- Op een site van het ministerie van Economische Zaken konden mensen gedurende een paar maanden vertellen wat zij als tegenstrijdige regels ervaren. ${ }^{1}$ Er kwamen 519 reacties en die bevatten 784 klachten over regels. Zo de in een bedrijfskeuken verplichte gladde vloer vanwege de hygiëne en de tegelijk juist verplichte geribbelde vloer vanwege de veiligheid; of de situatie dat de bouwvergunning niet wordt afgegeven als er geen milieuvergunning is, terwijl de milieuvergunning alleen wordt afgegeven als er een bouwvergunning is.

- Volgens het onderzoeksinstituut EIM klagen ondernemers over de hoeveelheid wetten en de hoge administratieve lasten en andere kosten die deze meebrengen. Alleen al het voldoen aan de jaarlijks terugkerende informatieverplichtingen kost het bedrijfsleven ruim 12 miljard euro. ${ }^{2}$ Ook burgers hebben last van administratieve lasten als zij in aanmerking willen komen voor producten van de overheid, bijvoorbeeld op het terrein van de zorg. Zelf heb ik nog nooit het IKAPformulier zo kunnen invullen dat de door het rijk beoogde bijdrage aan een PC of fiets eruit kwam. Ik heb het opgegeven.

- Los van lasten is er nog een ander kwaliteitsprobleem: men kan regelmatig lezen dat wetten niet of onvoldoende werken of effecten hebben die niet waren beoogd. De Wet orgaandonatie leidde tot minder donoren, de Plukze-wetgeving leverde althans jarenlang nauwelijks wat op, het VMBO is van oplossing een probleem geworden. Er was kennelijk iets mis met de kwaliteit van die wetgeving. En zoals Niessen al zei: voor een slechte wet betaal je drie keer. 3

Het kan nog erger.

- De Wetenschappelijke Raad voor het Regeringsbeleid (WRR) meent dat de rechtsstaat in gevaar is.4 Dat zit vooral in de onvoldoende handhaving van de wetgeving en in de wetgeving zelf. De overheid wil

1 www.strijdigeregels.nl.

2 Zie Nijsen, 2004.

3 In een interview door R .de Krey, Management \& Bestuur, april 2003.

4 Rapport 63. Het kabinet deelt die zorg, zie kamerstukken II, 2003/2004, 29279, nr. 1. 
via wetgeving maatschappelijke problemen aanpakken en daarbij zo direct mogelijk aansluiten op de variatie in de samenleving. Dat leidt tot veel, tot gelaagde en gedetailleerde wetgeving en tot snelle wijzigingen van de bestuurswetgeving. Tegenstrijdigheid en onoverzichtelijkheid zijn het gevolg. Zo bijt de rechtsstaat, bedoeld om zekerheid en bescherming te verschaffen, zich als het ware in zijn eigen staart.

- De Europese regelgeving verhevigt de normenvloed, aldus de WRR. Er zijn schattingen dat meer dan de helft van de Nederlandse regelgeving uit Brussel komt of van daaruit sterk beïnvloed wordt. 5 Over de kwaliteit van de Europese regels kan men horen: er zijn er te veel van, ze zijn te gedetailleerd of juist te vaag, ze passen niet steeds in ons systeem, ze zijn moeilijk uitvoerbaar en handhaafbaar. 6

Genoeg problemen dus met de wetgeving. Nu wordt sinds 1951 een wetgevingskwaliteitsbeleid gevoerd. De gerechtvaardigde vraag is dan: wat is er aan de hand met de kwaliteit van wetgeving en wat is de betekenis van het wetgevingskwaliteitsbeleid daarin. Daarover zal ik het vandaag hebben, onder de titel: 'De wet als zinsbegoochelingstoestel'.

De opbouw van mijn verhaal is als volgt:

a. Problemen met wetgeving spelen op verschillende niveaus.

b. De wet is een vat vol paradoxen en afwegingen, de kwaliteitseisen zijn geen kwaliteitseisen, en dus is de kwaliteit van een wet niet eenduidig vast te stellen.

c. De wet is primair een beleidsinstrument, de ellende van de wet is de ellende van het beleid.

d. De barrière van het wetgevingskwaliteitsbeleid werkt onvoldoende door gebrek aan kennis, door de invloed van de politieke rationaliteit en door de juridische inbedding van het kwaliteitsbeleid.

Nog een opmerking vooraf. Mijn betoog betreft de kwaliteit van wettelijke regels, zowel de Haagse als mutatis mutandis de Brusselse regels.

5 o.a. Brinkhorst, Symposium Raad van State, 2002, p. 36. Staatssecretaris Nicolaï komt op basis van departementale opgaven tot $60 \%$, zie Voermans, 2004 . We mogen eigenlijk wel zeggen dat het Europese recht voor 100\% doorwerkt, omdat een aantal spelregels algemeen geldt; en dus dient bij elk wetsvoorstel de verhouding tot Europeesrechtelijke regels te worden bepaald.

6 Vgl. bv. De Wilde, 2000. 


\section{Uiteenlopende problemen}

\subsection{Verschillen in de tijd}

De kritiek op wetgeving is al oud en deels dezelfde als nu te horen is. In Nederland komt die kritiek aan het eind van de negentiende en het begin van de twintigste eeuw. Drucker schrijft in 1915 dat: "de Nederlandsche wetgever op het gebied van de kunst van wetgeving geen reputatie te verliezen heeft". Hij heeft het oog vooral op de weinig heldere taal, de vele Latijnse en andere vreemde woorden die in wetten staan. leder moet zijns inziens een wet kunnen lezen en begrijpen.

Al vroeg wordt de klacht over afstemmingsproblemen geuit. Fockema Andreae signaleert die in 1913; later, in 1977 zullen S.O. van Poelje en J.M. Kan dat doen, Van Poelje in zijn beroemde preadvies over de veertien wetsfamilies.7

Van recenter datum is de kritiek op de hoeveelheid wetten. Genoemde Kan klaagde in 1977 over de wetgevingsexplosie van de 25 jaar ervoor. In de jaren tachtig kreeg deze wetgevingsneiging een medische benaming: legisferitis. Schuyt wijst in zijn oratie uit 1982 ook op het sterk gegroeide aantal regels; wij leven in een gereglementeerde wereld. Sinds 1980 hebben de achtereenvolgende kabinetten zich bezorgd betoond over de groei van de regelgeving en een dereguleringsbeleid gevoerd, al gebeurde dat onder verschillende inzetten (minder regels, bevordering economische ontwikkeling, beter bestuur).

De laatste jaren is overigens de aandacht of kritiek behalve op de hoeveelheid regels, gericht op de uitvoering en handhaving van wetgeving.

\subsection{De ambiguïteit van wetgeving}

De klacht dat er zoveel regels zijn, werd geuit zonder dat men eigenlijk wist hoeveel regels er waren. Sinds kort hebben we daar iets meer zicht op. In de wettenbank van de Sdu staan ongeveer 1750 wetten, 2750 amvb's en 7800 ministeriële regelingen. In totaal zo'n 12.300 regelingen. Die 12.300 publieke regels tellen samen ongeveer 140.000 artikelen. ${ }^{8}$ Er zijn overigens nog meer publieke regelingen, zoals de rechtstreeks

7 Zie het overzicht in Veerman, 2001

8 RUG, 2004 
werkende Brusselse, die van provincies en gemeenten, van product- en bedrijfschappen en van ZBO's.

De veelheid der wettelijke regels is echter in zekere mate bedrieglijk. Ik stip aan dat de toename van regels deels te zien is als een kwestie van juridisering. Vroeger leefden mensen in hun verbanden in waarschijnlijk eveneens een woud van regels, zij het informele.9 Met het wegvallen van die verbanden is een aantal van dergelijke regels verstatelijkt, zoals een deel van de sociale wetgeving.

Daarbij komt dat mensen gemak hebben van afzonderlijke regels. Ik denk aan de duizenden regels van het burgerlijk recht of van het verkeersrecht, de vele veiligheidsnormen voor ons voedsel, de rechtspositieregelingen. En ik wed dat naast alle regels die er zijn, u, uw eventuele partner en gezinsleden elkaar nog de nodige impliciete of expliciete regels hebben gesteld.

Het gaat om de regeldruk. Niet alle regels komen op dezelfde hoofden of dezelfde plekken terecht. De potentiële regeldruk (het aantal regels), de feitelijke regeldruk (de werkelijke lasten) en de gepercipieerde regeldruk (de irritatie) ${ }^{10}$ verschillen. De kritiek op de wetgeving wordt gekleurd waar voor de nodige wetgeving geldt dat de voordelen soms diffuus zijn en terecht komen bij de samenleving als geheel (het algemeen belang), maar de lasten ervan terecht komen bij een beperkt aantal justitiabelen en direct voelbaar zijn. Dat kan ook het geval zijn waar niet of selectief gehandhaafd wordt en de regeldruk ongelijk ondervonden wordt. Als er gemeentelijke regels zijn over de omvang en plaats van reclameborden op bedrijven, die niet gehandhaafd worden en als om reden van een nieuwe start van een handhavingsbeleid er nieuwe regels komen over de omvang van reclameborden (ze moeten bijvoorbeeld $400 \mathrm{~cm}^{2}$ kleiner), dan voelen de goedwillende bedrijven zich wel bekocht.

Dat het een selectief probleem is, blijkt ook hieruit dat de lasten worden gesignaleerd ten aanzien van specifieke wetgeving zoals de Arbeidsomstandighedenwet en de bouwregelgeving en voor bepaalde sectoren zoals de horeca, de bouw, de zorg en het onderwijs. ${ }^{11}$ De klach-

9 Niet alleen. De Leidse lakenindustrie, bijvoorbeeld, was via een keur tot in detail geregeldzie J.W. Marsilje (red.), Leiden, de geschiedenis van een stad, dl. I, Leiden, 2002, p. 106/107

10 ECRYS/NEI, Regeldruk voor OCW-instellingen.

11 Zie strijdige wetten, Knelpuntenonderzoek veiligheidsregelgeving en Regeldruk voor OCW-instellingen. 
ten over de administratieve lasten betreffen ook niet alle lasten- het opstellen van jaarrekeningen, bijvoorbeeld, vindt het bedrijfsleven nuttig. ${ }^{12}$

De paradox is dat enerzijds geklaagd wordt, zeker ook vanuit de politiek, dat er te veel en te gedetailleerde wetgeving is en de lasten hoog zijn, maar dat er tegelijkertijd een enorme honger naar regelgeving is. ${ }^{13}$ Er hoeft maar weinig te gebeuren of vanuit de regering, de Kamer of vanuit maatschappelijke kring wordt de wens geuit regels te maken voor dat probleem. Er is een krasse zestiger die in een manege betrapt wordt met pony's en prompt besluit de minister van LNV na enige publicitaire verontwaardiging een wet te maken waarin seks met dieren wordt verboden. Op basis van krantenberichten zijn er tientallen voorbeelden te geven dat, al dan niet vanuit incidenten, om wetgeving wordt gevraagd.

Het bedrijfsleven klaagt over de veelheid aan regels en het is waar dat veel lasten daar terecht komen (zoals in de sfeer van de loonadministratie, de BTW en de Warenwet14), maar het klaagt evenzeer dat er te weinig regels zijn, bijvoorbeeld op het vlak van de ICT. Hetzelfde ziet men bij deregulering. Marktpartijen zijn vaak helemaal niet happig op andere of minder regels: de bestaande regels beschermen juist hun positie tegen nieuwkomers en hun administratief proces is erop ingericht. 15

\subsection{Problemen op macro-, meso- en microniveau}

Uit mijn inleiding blijkt dat problemen met wetgeving zich op verschillende niveaus bevinden.

Op macroniveau spelen, zoals gezegd, de hoeveelheid en gedetailleerdheid van de wetgeving, de onkenbaarheid en het verlies aan bescherming en zekerheid. Ook zou de veelheid van wetten een risico vormen voor ondernemingszin en innovatie. ${ }^{16}$

12 Nijsen, RegelMaat, p.53.

13 De bevolking verwacht veel van de overheid, zo blijkt uit SCP-rapporten (zie Vos en van Doorn, 2004). Europees Commissaris Erkki Liikanen zei op een bijeenkomst op 28 april 2004 (Brussel) dat het probleem is dat mensen volop, maar risicoloos willen leven.

14 Dit zijn de informatielasten, daarnaast heeft het bedrijfsleven andere nalevingslasten.

15 vgl. Andriessen; zie bijvoorbeeld de kritische opmerkingen van KLM president-directeur Van Wijk bij de plannen tot privatisering van Schiphol (NRC, 11-3-04) .

16 Vgl. Arre Zuurmond in NRC, 14-2-04. 
Op mesoniveau hebben specifieke diensten, groepen of individuen last van regels als gevolg van fricties tussen regels en cumulatie van lasten ${ }^{17}$, zoals de verschillende gegevens die bedrijven aan diverse overheidsorganen moeten leveren of de afstemming van toezicht in productketens (zoals de afvalketen).

Op microniveau zijn er twee verschillende soorten problemen. In de eerste plaats de direct uit afzonderlijke wetten voortvloeiende lasten. In de tweede plaats weet de overheid met wetten niet steeds de gewenste effecten te bewerkstelligen. Burgers hebben daar last van, maar ook de samenleving als geheel waar falend beleid tot kosten leidt.

Voor de vervulling van een leerstoel, zeker aan deze Universiteit, is het wel prettig dat er problemen zijn, al zijn ze te relativeren zoals hierboven bleek. Ik zal in deze rede de nadruk leggen op de kwaliteit van afzonderlijke wetten- het probleem begint op het microniveau.

17 Van regels vanuit verschillende invalshoeken en verschillende bronnen (departementen, gemeenten), vgl. DHV, p. 37/38. Men kan wel zeggen, zoals in het rapport van DHV, dat deze problemen geen wetgevingsproblemen zijn maar uitvoeringsproblemen, zij vloeien wel voort uit wetgeving en zijn m.i. daarom te relateren aan de kwaliteit van wetgeving. 


\section{Over de kwaliteit van wetgeving}

\subsection{Het begrip 'kwaliteit'}

De eerste stap bij de bespreking van de vraagstelling is te bezien of er een min of meer geobjectiveerde maatstaf is voor de kwaliteit van wetgeving.

Dan weten we waarover we praten. Het Instituut Nederlandse Kwaliteit (INK) geeft een definitie van 'kwaliteit' die men vaker tegen komt in de literatuur daarover. Die definitie luidt:

"De kwaliteit van een product of dienst is de mate waarin het geheel van eigenschappen voldoet aan de gebruikersverwachting van de klant, begrensd door de prijs en de levertijd die hij wil betalen en accepteren, en de ethische en professionele waarden van de leverancier."

'Kwaliteit' gaat dus wel over de eigenschappen van een product, maar kwaliteit is niet een inherente eigenschap van dat product. De kwaliteit wordt uiteindelijk bepaald door externe factoren, het is het oordeel van de makers en gebruikers. De klant is in wezen koning. ${ }^{18}$ De klant is overigens een verzamelbegrip. Potentiële klanten hebben niet noodzakelijk dezelfde verwachtingen over het product. Wat de een kwaliteit vindt, dat hoeft de ander niet zo te vinden. Een ijzeren zwemvest kan een prachtproduct zijn, maar het zal niet aan de gebruikersverwachting van alle klanten voldoen. Aangenomen dat ze hun oordeel nog kunnen geven.

Ik maak een korte zijstap naar de beeldende kunst. Daar is wel discussie geweest over de vraag wat kunst is, in tegenstelling tot bijvoorbeeld kitsch. Daarbij is gepoogd objectieve criteria van goede smaak te bedenken. Dat is niet gelukt. ${ }^{19}$ Tegenwoordig wordt op het terrein van de esthetiek het criterium van de goede smaak weinig meer gebruikt.

18 Aldus ook Bentlage c.s, die kwaliteit zelfs louter omschrijven als 'het voldoen aan de verwachtingen van de klant' (p.19).

19 Denk ook aan de verdwenen discussie over 'vorm' of 'vent' als kwaliteitscriteria voor literaire werken. Overigens kan men daaruit afleiden dat er op zijn minst uiteenlopende criteria bestonden. 
Men is eraan gewend geraakt dat er verschillende smaaksystemen naast elkaar bestaan. ${ }^{20}$ Ook een intellectueel mag kitsch mooi vinden. Zoals de kunstverzamelaar Martijn Sanders zegt: ik vind dat wat je ontroert, goed is. Dat is geen esthetisch criterium. Op de vraag van de kwaliteit van kunst geven de toeschouwers het antwoord. ${ }^{21}$ Wat de kijkers zien en hoe zij het bekekene waarderen, kan erg verschillen. Ik citeer een stukje uit de NRC van 24 januari van dit jaar, over een bezoek van Guus Middag aan de kunstenaar Mark Bisch of die zinsbegoochelingstoestellen maakt. Er staat in diens atelier een kamergroot kinetisch kunstwerk dat Middag ervaart als een gedicht van Hans Favereij. Middag schrijft dan:

"De kunstenaar hoort het welwillend aan, maar wijst er op dat tot nu toe iedere bezoeker iets anders in de grote machine had gezien. De een zag een enorme productiehal. Of een casino, met rouletteballetjes. Een ander zag een flat met stijgende en dalende liften. Een distributiecentrum. [..........] Volgens sommigen had het geheel ook wel iets van een groot muziekinstrument, een ruisharp, een walvisskelet. Naarmate het ding meer op drift raakte, begon het volgens anderen steeds meer op een achtbaan te lijken, een pretpark, vijf Prins Clauspleinen boven elkaar. Een beeld voor het leven met al zijn toevallige ontmoetingen en botsingen en verlatingen. Bischof had het grote ding, zoals hij het in de wandeling noemde, geen naam gegeven. In de hoofden van de kijkers zag het er toch steeds weer anders uit."

Zo is het ook met het kunstwerk 'wetgeving', zoals ik zal laten zien.

20 Kraaijpoel, p.51, 53. Daarvoor in de plaats is ook wel de opvatting gekomen dat kunst een schok teweeg moet brengen. Dat hoeft niet een esthetische schok te zijn, getuige de rondzending van het illegalenformulier naar ruim 200.000 adressen, door Martijn Engelbrecht, een maatschappelijk geëngageerd kunstenaar die mensen met 'schijnbare zekerheden'wil confronteren. (Volkskrant 12-1-04). Zie ook A. de Swaan, dat kwaliteit een kwestie van klasse is, resultaat van sociale processen van professionalisering en distinctie bij de opkomst van sociale groepen.

21 Nausicaa Marbe, Ik ben de ultieme consument van kunst- interview met Martijn Sanders, directeur van het Concertgebouw, VN, 19 juli 2003, p. 22-26. 


\subsection{De kwaliteit van wetten}

Het oordeel over de kwaliteit van een product, dus ook het product 'wet' wordt bepaald door de makers en de gebruikers. Om reden van systematiek begin ik met het product zelf, de wet.

De wet is een rechtsbevel22, zij bevat de bindende regels van de overheid. Wetten worden primair gemaakt om iets te bewerkstelligen in de samenleving. ${ }^{23}$ De inhoud van de wet is uiteindelijk een kwestie van politiek, van een keuze hoe de samenleving in te richten en welke waarden daarbij van belang zijn. De impuls tot nieuwe wetgeving of wijziging van oude is velerlei: nieuwe technologische of maatschappelijke ontwikkelingen die nieuwe problemen opleveren (ICT, nieuwe ziekten), een nieuw kabinet dat een eigen gezicht wil tonen, Brussel, bezuinigingen, jurisprudentie, problemen bij de uitvoering of handhaving, maatschappelijke incidenten of nieuwe inzichten. ${ }^{24}$ Via beleid en wetgeving reageert de overheid daarop door een koers te bepalen, een oplossing te bedenken, maatregelen uit te voeren. Een wet fungeert als voertuig van beleid doordat zij een institutioneel kader en bevoegdheden schept, risico's verdeelt en bescherming biedt25, alsmede geldstromen en gedragsregels van een legale basis voorziet. ${ }^{26}$ Het beleid, de

22 Zie R. van den Berg, 2003. In het 'moderne wetsbegrip', dat uit het gedachtegoed van de Verlichting stamt, gaat het om de bescherming tegen de willekeur van de overheid door de democratische vaststelling en de algemeenheid; de rechtszekerheid en wederkerigheid, de stabiliteit zijn inherente elementen. Dat is m.i. overigens steeds in hoge mate een geidealiseerd begrip geweest. In de praktijk werd en wordt de wet gebruikt om de samenleving te ordenen. zie ook noot 86.

23 J. van der Hoeven, De drie dimensies van het bestuursrecht.

24 Bijvoorbeeld dat psychiatrische patiënten juist wel of juist minder goed op zichzelf kunnen wonen.

25 De beschermingsfunctie en schepping van een juridische infrastructuur via de wetboeken horen m.i. ook tot de instrumentele functie: de bescherming tegen de overheid (via het wetsbegrip (zie noot 22) en door specifieke bepalingen zoals in de Awb) en tegen maatschappelijke machten.

26 Dat is overigens iets anders dan een wet als een middel tot 'social engineering' te zien. 
uitwerking van de politieke keuze, wordt waar het bevoegdheden en middelen nodig heeft en verplichtingen wil opleggen, gehuld in de juridische vorm van de wet. 27

Het toenmalige kabinet heeft in 1991 in de nota Zicht op Wetgeving een aantal algemene kwaliteitseisen vastgelegd. De kwaliteitseisen zijn genummerd van een tot zes. Terzijde moet mij van het hart dat als je ze telt, het toch echt twaalf verschillende kwaliteitseisen zijn. Het zijn overigens eisen voor wetsvoorstellen, niet voor een wet. ${ }^{28}$

Ik noem ze.

1. rechtmatigheid (niet in strijd met hoger recht) en verwerkelijking van algemene rechtsbeginselen

2. doeltreffendheid en doelmatigheid

3. subsidiariteit en evenredigheid (niveau van regulering en kosten: baten)

4. uitvoerbaarheid en handhaafbaarheid

5. afstemming met andere regelingen

6. eenvoud, helderheid en toegankelijkheid. 29

Zoals men kan zien, zijn de eisen gericht op wetgeving die kan werken. De meeste eisen zijn van beleidsmatige aard; rechtmatigheid en

27 Dat is niet zonder betekenis. De procedure biedt een garantie. Maar er is meer. Al komt het recht naar mijn waarneming en opvatting (in die volgorde) niet van boven of van buiten, er is wel een rechtsgebouw, er zijn beginselen waarvan 'wij' kortere of langere tijd vinden dat ze richtinggevend zijn voor de inhoud van regels. Voor een deel zijn die regels vastgelegd, zoals in Grondwet of internationale verdragen, voor een deel zijn het rechtsbeginselen- in elk geval horen ze tot de habitat van de wet.

28 Een wetsvoorstel en een wet zijn verschillende producten. De Tweede en Eerste Kamer zijn niet gebonden aan de kwaliteitseisen voor de wetgeving zoals in de Aanwijzingen verwoord.

29 Deze kwaliteitseisen zijn herbevestigd in de nota 'Wetgevingskwaliteitsbeleid', Kamerstukken II, 2000/01,27475, nr. 2; In 'Brussel' zijn de kwaliteitseisen minder prominent, al staan in het Mandelkernrapport (final report, 13-11-2001, p.i, 9/10) en, zij het wat minder, in de recente 'Gemeenschappelijke praktische handleiding voor de opstelling van communautaire wetteksten' (Luxemburg, 2003) wel verwante criteria.

De Raad van State hanteert een vergelijkbare indeling: de wetstechnische, juridische en beleidsanalytische toets. 
afstemming zijn juridische eisen; eenvoud, helderheid en toegankelijkheid noem ik technisch. 30

Deze Nederlandse standaard is na 1991 uitgewerkt in de 'Aanwijzingen voor de regelgeving' en verder in een aantal leidraden en checklists die de wetgevingsjurist en de beleidsmedewerker helpen bij het maken van beleid en de daarbij horende regelgeving. Op de site van het Kenniscentrum Wetgeving hebben we daarvan een verzameling, die bestaat uit zo'n 40 documenten. Ik noem de checklist voor de regeling van toezicht, de handleiding 'Normalisatie en certificatie', of 'de tafel van 11 'om de naleefbaarheid van een voorgenomen wet te voorspellen. Voor een belangrijk deel zijn echter de kwaliteitseisen algemeen gebleven. Het belangrijkste document, de Aanwijzingen, bevat voornamelijk wetstechnische aanwijzingen. Die zijn wel specifiek. De juridische aanwijzing van de rechtmatigheid is al veel minder uitgewerkt. De beleidsmatige kwaliteitseisen zijn open gebleven. Ter compensering worden procesmatige aanbevelingen gedaan: consulteer uitvoerende en/ of handhavende instanties.

Daarmee is getracht een soort professionele standaard neer te zetten en is een raamwerk gegeven voor een discussie over de kwaliteit van wetgeving. Deze kwaliteitseisen zijn echter geen kwaliteitseisen, maar aandachtsgebieden. Om twee redenen.

In de eerste plaats zijn ze te open. Je hebt niet voldoende houvast te bepalen of het wetsvoorstel eraan voldoet. Bij de relatief duidelijke eis van helderheid kan men vragen: helder voor wie; over de rechtmatigheid kan men van mening verschillen, zoals regelmatig blijkt uit de advisering door de Raad van State. Verbieden bijvoorbeeld de vrijheid van godsdienst en onderwijs dat je extra bijzondere eisen mag stellen aan allochtone scholen? Sommigen vinden dat je best die eisen kan stellen, anderen niet. De beleidsmatige kwaliteitseisen, zoals de doeltreffendheid en uitvoerbaarheid, zijn niet ingevuld en spreken eerder verwachtingen uit betreffende de toekomst. Het zal nog moeten blijken of aan die eisen wordt voldaan. Wat doeltreffend en doelmatig is, hangt bovendien af van veel factoren waaronder de definitie van het probleem en van de oplossing. Daarover kan men van mening verschillen.

30 De in de inleiding genoemde problemen zijn te beschrijven in termen van deze kwaliteitseisen. 
In de tweede plaats zijn de kwaliteitseisen potentieel tegenstrijdige eisen. Een voorbeeld. De subsidiariteit houdt onder meer in dat men bevoegdheden en plichten legt op een zo laag mogelijk niveau. Dat levert een gelaagde wetgevingsstructuur op waarin het nodige gedelegeerd wordt bijvoorbeeld naar gemeenten of minister. Uit oogpunt van helderheid kan dat een probleem opleveren.

De doeltreffendheid en de rechtmatigheid blijken vaak op gespannen voet met elkaar te staan. Ik verwijs naar het onderzoek van enkele Maastrichtse collega's.31 Denk aan een snelle aanpak van de bescherming tegen het wassende water door dijkverbetering tegenover rechtsbescherming voor de mensen die op of bij die dijken wonen en die hun bezwaren moeten kunnen aanvoeren; de laatste eis kan de eerstgenoemde wens van een snelle aanpak tegenwerken.

\subsection{De makers van wetten}

De professionele standaard van het kabinet als medewetgevend orgaan is zo vast nog niet. Er speelt bovendien meer. Bij de totstandkoming van een wet zijn de organen van de wetgever en diverse andere personen en instellingen betrokken.32 Zij koesteren waarden, hebben opvattingen over feiten, hebben belangen en ideële wensen, en zij projecteren die in de keuze voor en de inhoud van een wet.

In de agendabouwtheorie33 beschrijft men hoe een probleem een plek moet verwerven op de wetgevende agenda. Het gaat om de erkenning als probleem, als maatschappelijk probleem, als aan te pakken probleem, als door de politiek aan te pakken probleem. Dat kan een heel

31 Klosse, Peeters e.a.,2003, h. 10.3.

32 Volgens het totaalkwaliteitsbeheer moet de producent voortdurend de klant voor ogen houden en diens gedachten terugkoppelen naar het productieproces. Dat gebeurt ook. In het proces van voorbereiding van wetgeving worden zij, althans sommigen van hen, geraadpleegd en er zijn steeds pogingen geweest de klant te betrekken bij het besluitvormingsproces (denk aan de oude publiekrechtelijke bedrijfsorganisatie, referenda, inspraak of het modernere onderhandelend bestuur). Burgers, in alle facetten van hun bestaan, worden vertegenwoordigd door het parlement. Daar worden wetten gemaakt omdat het algemeen belang dat vergt. Bijzondere preferenties spelen wel mee, bijvoorbeeld omdat zij kiezersgroepen vertegenwoordigen. Dat er compromissen gesloten worden en dat er veel en gedetailleerde wetten komen, hangt daarmee juist samen.

D’Anjou, 1986. Overigens komt lang niet alle wetgeving 'van onder af": begrotingen, bezuinigingen, regeerakkoorden leiden evenzeer tot wetgeving. 
proces zijn, met personen die zullen proberen te verhinderen dat een probleem de politieke agenda bereikt. Daar wordt uiteindelijk besloten een wet te maken en begint de strijd om de inhoud.

Binnen de politieke arena heeft een wet allereerst de genoemde instrumentele functie, waarbij men denkt aan de aanpak of oplossing van het probleem. De overheid wil iets bereiken met wetgeving.34

Dan heeft een wet een epaterende functie, een wet is het zichtbare resultaat van de daadkracht van de minister. 35 Die levert potentieel politiek kapitaal op.

Een belangrijke functie is de probleemverplaatsende functie van de wet, in de zin dat zij een probleem van de politieke agenda afhelpt. Soms is het doel en vaak is het effect van een wettelijke regeling dat een probleem op het bord van een ander gelegd wordt (een ander overheidsorgaan, het maatschappelijke middenveld, het bedrijfsleven en zo meer). Dat is niet altijd iets onzindelijks, al krijgt soms een ander die verantwoordelijkheid zonder bruidschat 36 of tegen wil en dank. Denk aan de nieuwe Wet op het notarisambt.

Het resultaat van het krachtenveld binnen de politieke arena is daarbij soms dat er wetten komen die niet bedoeld zijn om te werken. Wetten voor de Bühne. Men noemt dit wel, in mijn ogen wat ongelukkig, de symbolische functie van de wet. Die komt dicht bij de waardeexpressieve functie. Wetgeving is soms het resultaat van politieke druk van bepaalde groepen in de samenleving die hun waarden en normen graag van een officieel waarmerk willen voorzien door die wettelijk vast te leggen. Een oud voorbeeld is dat de invloedrijke leden van de dierenbescherming, afkomstig uit de gegoede burgerij, erin slaagden te komen tot algemene bepalingen inzake de bescherming van dieren. Specifieke wensen met economische consequenties, zoals het verbod van trekhonden, werden overigens niet gehonoreerd. 37

34 Dat wil niet zeggen dat de sturingspretentie ook gerealiseerd wordt.

35 Op Justitie krijgt traditiegetrouw de minister bij zijn vertrek een bundel met zijn wetten. Op VWS kreeg minister Borst de bundel 'Wetgever Borst, Overzicht van het wetgevingsoeuvre van dr. E. Borst-Eilers als minister van VWS, Den Haag'.

36 Een voorbeeld: in de nieuwe Wet werk en bijstand krijgen de gemeenten de verantwoordelijkheid voor en het belang bij de uitvoering ervan, maar werd wel in dat kader het gemeentefonds gekort met 240 miljoen euro, aldus VNG-voorzitter Pans tot zijn ongenoegen (P.M. Den Haag, februari 2004, p. 27) .

37 Davids, 1987. 
De politicoloog Van Schendelen benoemt als functie van wetgeving de consoliderende. Een wet is een gestolde belangenstrijd waarin de diverse belanghebbenden en betrokkenen hun opvattingen en belangen voor dat moment hebben vastgelegd. 38

Een wet blijkt zo een compromis te zijn. Dat is overigens niet alleen een compromis vanwege verschillende belangen. Volgens Snellen, in zijn Tilburgse oratie39, komen vier rationaliteiten in een wet samen: de politieke, de juridische, de economische, de wetenschappelijke. Rationaliteiten zijn niet tot elkaar te herleiden invalshoeken met eigen inhoud en eigen waardepatronen. Soms lopen zij samen op, vaak zijn ze tegenstrijdig. Voor de wetenschappelijk gezien beste aanpak van een probleem is bijvoorbeeld geen geld of geen juridische basis beschikbaar.40

Het kabinet beslist veelal of een wet er komt en welke functie die heeft, de nadere invulling en voorbereiding vindt plaats op de departementen. Rosenthal heeft gewezen op het bureaupolitieke aspect bij de voorbereiding van beleid en wetgeving, de strijd tussen a mbtelijke afdelingen. ${ }^{41}$ Dat is, voeg ik daaraan toe, niet louter een bureaucratische aangelegenheid. Ambtelijke afdelingen representeren zorg voor specifieke maatschappelijke belangen en hebben daarbij contact met hun veld. Dat moet ook. Bij nieuwe voornemens kijken afdelingen naar wat die voor hun veld (daarbij overigens inbegrepen: hun positie) zullen betekenen. Zij brengen, onder ministeriële dekking, dat belang in in het overleg over de noodzaak en inhoud van een wettelijke regeling.

$E r$ is niet alleen een strijd tussen beleidsvelden. De relatie tussen de wetgevingsjuristen en 'het beleid' ligt eveneens genuanceerd.

38 Van Schendelen, NJB 1978, p.833/834. Zo bijvoorbeeld ook de in het WRR-rapport 63 genoemde Waldron (p.239).

39 Boeiend en geboeid, 1987.

40 In wetgeving moet een evenwicht gevonden worden op een aantal assen, zoals die van maatschappelijke wensen en financiële mogelijkheden, van vrijheid en veiligheid, van precisie en algemeenheid, van actualiteit en continuïteit, van publieke baten en individuele lasten.

41 Rosenthal, 1988. 
Beleidsmedewerkers beschouwen wetgevingsjuristen als remmers in vaste dienst. 42 Het genoemde verschil in waardering van de kwaliteitseisen 'doeltreffendheid' enerzijds en 'rechtmatigheid' anderzijds, vindt men daarin terug.

De diversiteit in waardering van kwaliteitseisen bestaat ten slotte ook bij kamerleden. Die hebben, aldus inmiddels oud-kamerlid Marja Wagenaar, op zich niet zoveel interesse in de kwaliteit van wetgeving.43 Als expliciet aan kamerleden wordt gevraagd naar hun opvatting over kwaliteit van wetgeving zoals Dorbeck-Jung deed, dan scoren uitvoerbaarheid en handhaafbaarheid hoog, terwijl rechtmatigheid en rechtvaardigheid laag scoren. De doeltreffendheid en doelmatigheid scoren eveneens laag.44

De makers van wetten bekleden verschillende posities en die brengen verschillen van inzicht mee over de functie, betekenis en wenselijke inhoud van een wet. Een eenduidig oordeel over de kwaliteit van wetgeving bij hen, valt niet aan te nemen.

\subsection{De klanten: de scheiding tussen de wet in wording en de wet in werking}

In het kwaliteitsdenken speelt de klant een cruciale rol. In geval van wetgeving wordt 'de klant' als een gevaarlijke metafoor gezien omdat deze verwijst naar consumentisme in plaats van burgerschap. Het alternatief 'normadressaten' klinkt weer te afstandelijk. Laten we zeggen: er zijn veel personen en instellingen tot welke de wetgever zich richt: de samenleving als geheel, uitvoerders, handhavers, rechters, instellingen, bedrijven, burgers. 45

42 Sommige wetgevingsjuristen zien in het meedenken en de confrontatie met het beleid het mooie van hun vak- maar het is wel een confrontatie. Anderen zien zich meer als de juridische vertalers van beleid. In beide posities kunnen de wetgevingsjuristen door de beleidsmedewerkers en bewindslieden als hinderlijk ervaren worden. Beide groepen ambtenaren hebben het oog gericht op verschillende rationaliteiten en belangen. Overigens bestaan binnen de groep van wetgevingsjuristen wederom verschillende opvattingen over wat een goede wet is: een juridisch kloppende, een heldere en een werkende (zie mijn 'Het meesterschap...; dit beeld werd bevestigd in een enquête onder wetgevingsjuristen, MvJ, 2003).

43 Althans toentertijd, zie Wagenaar,1999-6 (en waarschijnlijk nog steeds, al heeft het Bureau Wetgeving van de Kamer het onderwerp wel op zijn agenda geplaatst).

44 2003-4.

45 De makers hebben verschillende klanten voor ogen: de voorbereidende ambtenaren primair de bewindspersonen, de bewindspersonen naast de samenleving het parlement, de wetgever de samenleving of segmenten daaruit, de belangenbehartigers en lobbyisten hun achterban. 
Er bestaat een groot verschil tussen de wet als product van politieke besluitvorming en de wet in werking. Dat is op zich al een oud inzicht, getuige Roscoe Pounds gevleugelde onderscheid tussen 'law in the books' en 'law in action'.

Schuyt heeft in zijn oratie van 1982 gewezen op het transformatie- en correspondentieprobleem dat inherent is aan wetgeving: de aansluiting van de relatief digitale wet op de analoge, veelvormige werkelijkheid, en omgekeerd de vertaling van maatschappelijke situaties in de terminologie en inhoud van de wet. Daar ontstaat ruis. Dat wordt alleen maar sterker als men de tijdsfactor daaraan toevoegt. Op het moment dat de wet er is, is de samenleving waarvoor die wet was bedoeld al weer veranderd. Of breder nog. De samenleving ontwikkelt zich verder en nieuwe situaties moeten dogmatisch worden gemasseerd om in het oudere wettelijk stelsel te passen. 46

De scheiding tussen de wet in wording en de werking ervan is voorts wezenlijk in de zin dat een wet in een politieke omgeving tot stand komt, maar vervolgens in een maatschappelijke setting terecht komt, met andere partijen, belangen, loyaliteiten, machtsverhoudingen. Mensen gaan met de woorden van de wet aan de gang. Of niet. Een wet komt niet in een sociaal of juridisch vacuüm terecht, maar in wat rechtssociologen noemen: een 'semi-autonomous social field'47, een veld waar al regels en gewoonten gelden. Een wet moet zich als het ware invechten in dat veld. Sommigen zullen de wet als een kans zien, anderen als een bedreiging.

Daarbij komt dat het semi-autonome veld gelaagd is. Regels werken via intermediaire processen en instituten, via uitvoerings- en handhavingsarrangementen. Al die verschillende actoren die alle op een andere manier met een wet van doen hebben, hebben afhankelijk van hun belang, positie, taak en opvattingen of waarden, een oordeel over de zin en de kwaliteit van een wet en in hun gedrag bepalen zij ook de beteke-

46 Ongeregeld Heden, p. 33 e.v. Vgl. ook P.Tops, die meent dat de institutionele logica van de overheid botst met de situationele van de burger (Publiek Management, december 2003, p. 11). Concreet is het bijvoorbeeld te zien in de problemen met de uitleg en toepassing van de Wet op het bevolkingsonderzoek (evaluatie, p. 62).

47 Het beeld is van Sally Moore (opgenomen in : Een kennismaking met de rechtssociologie en rechtsantropologie, 1999-2). 
nis van die wet. ${ }^{8}$ Met de overgang naar de status van wet in werking verandert de wet in zin en betekenis.

\subsection{Perfect bestaat niet}

'Perfect bestaat niet', zegt mijn vrouw altijd, en dat tot mijn teleurstelling want zij kent mij toch al 34 jaar. En zo is het met wetgeving. De perfecte wet bestaat niet. Dat is een open deur, maar ik neem waar dat dat idee wel bestaat.49 Die open deur moet dus soms geopend worden.

Vanuit het begrip kwaliteit bezien, vanuit het product 'wet' bezien, en vanwege de vele betrokkenen zal de kwaliteit van een afzonderlijke wet nooit eenduidig zijn. De betekenissen van een wet worden in politieke en maatschappelijke contexten bepaald. De kwaliteitseisen hebben de schijn van rationaliteit en vanzelfsprekendheid. In hun vanzelfsprekendheid verhullen echter zij de inherente spanningen die in wetgeving besloten liggen. Het kwaliteitsoordeel kan per arena en per functie en per rol verschillen.

Dat wil niet zeggen dat de technische, juridische en beleidsmatige kwaliteitseisen geen zin hebben. Ze wijzen op relevante aspecten om te bewerkstelligen dat een wet zo goed mogelijk zal werken. De werking is echter soms een probleem. Waarom dat zo is, is hier inmiddels voor een deel wel duidelijk geworden (afweging van belangen, verschillende percepties over kosten en baten). Er is meer.

48 De waardering kan daarbij eveneens beïnvloed worden door de wijze van uitvoering en van handhaving (vgl. ook Niessen, RegelMaat, p. 90).

49 Vgl. Kloosterman, c.s. (2002, p.63):"In de praktijk kan en zal niet altijd absoluut perfecte regelgeving gecreëerd worden." 


\section{De ellende van de wet is de ellende van het beleid}

\subsection{Wetgevingskwaliteit als beleidsprobleem}

In de politieke arena wordt beslist hoe men de samenleving of stukjes samenleving wil inrichten, hoe men de risico's wil verdelen, welke bescherming men bieden, welke zorg verschaffen en welke kiezersgroepen men tevreden wil stellen. Daartoe wordt beleid gevoerd en wetgeving gemaakt. Welke functies ook de wet nog meer heeft, dit is de primaire en daar ga ik nu verder op in. Want op dat punt worden de problemen gemeld.

Beleid is de basis van de wet. Dat er een wet komt en wat daar in staat, is primair een beleidsbeslissing. Voor de meeste instrumenten heeft de overheid een wet nodig als legitimerende basis van instituties, bevoegdheden, geldstromen en verplichtingen. Vervolgens is ook beleid nodig om de woorden van de wet te verwerkelijken. Flankerend beleid.

Wetgeving bevindt zich op het niveau van woorden, van papieren intenties en instituties. Het gaat echter in de samenleving eigenlijk altijd om gedrag. Als de woorden van de wet willen werken, loopt dat via sociaal-psychologische processen van voorbeeldgedrag en conformering aan de sociale omgeving, beloning en straf, de behoefte aan zekerheid, de angst fouten te maken. Voor een materialist worden gedragingen en maatschappelijke ontwikkelingen bepaald door financieel-economische motieven maar ook door feitelijke en technische (on)mogelijkheden (denk aan wiel, pil, mobiel en camera). De klinisch psycholoog kan wijzen op het belang van gewetensvorming50, op mentale processen als gevoelens $5^{1}$ en percepties die het gedrag beïnvloeden. Voor de rationalist is gedrag het resultaat van de afweging van

50 Premier Balkenende wenste in het waarden en normen-debat (10-3-2004) dat ieder een politie-agent tussen de oren had. Hij had beter een goede ouder kunnen wensen want het geweten wordt gevormd in de vroege jeugd door de kwaliteit van de eerste objectrelaties (i.h.b.de ouders). Beleidsmatig zou je moeten investeren in maatregelen die -dreigende- tekorten hierin verhelpen (Bögels, p.30). Gelet op de opvattingen over de prestaties van de politie was het evenmin een gelukkige metafoor.

51 Zo noemen schuldeisers naast financiële motieven ook wraak als reden om geen minnelijke schikking met schuldenaren aan te gaan, aldus een WODC-evaluatie van de Wet schuldsanering (Den Haag, 2001). 
kosten en baten, waarbij kosten en baten een ruim palet vertonen; ook sociale en emotionele kosten en baten spelen een rol. Omgeving, geschiedenis en belangen indiceren zo ons gedrag. 52 Jonkers wijst aanvullend op het organisatievermogen en structurele mogelijkheden om regels om te zetten in handelen.53 Denk aan de communicatieve middelen ter verspreiding van (het gedachtegoed van) de wet en voorts aan al die maatregelen die nodig zijn voor de werking van de wet (personeel, competenties, prioriteitstelling, informatiesystemen, administratieve organisatie). De invoering van een wet, evenals de uitvoering en handhaving horen tot die organisatiestructuur. De wet draagt bij aan bepaald gedrag, maar er moeten dus meer condities worden vervuld, wil een wet werken.54 Die condities staan veelal niet in een wet, maar zijn een kwestie van beleid.

Veel van de genoemde kritiek, zowel op macro- als op microniveau, is niet op de wet als juridisch document gericht, maar op het beleid waarvan de wet het voertuig is. Het gaat soms goed, maar veel beleid gaat ook mis. De ellende van de wet is de ellende van het beleid.

\subsection{Falende kennis, falend beleid}

Voor het ontwerpen en voor de werking van wet en beleid is kennis nodig. Bij de realisering van politieke voornemens moeten twee sprongen worden gemaakt of bruggen geslagen:

- de vertaling van politieke slagzinnen, gedachten en theorieën op macroniveau naar beleid en wetgeving op microniveau, en

- de vertaling van het geformuleerde beleid en de daarbij behorende wetgeving in de uitvoering daarvan en de omgang daarmee.

52 Seidman c.S. (2001) noemen als verklarende oorzaken voor (probleem)gedrag: Rule, Opportunity, Capacity, Communication, Interest, Process, Ideology.

53 diss. 2003, p. $10 / 11$.

54 Willen de makers ervoor zorgen dat aan de kwaliteitseisen van wetgeving wordt voldaan, zullen zij de maatschappelijke feiten en processen grondig moeten bezien. 
De keuze van beleidsmaatregelen en de uitvoering van beleid en wetgeving gebeurt aan de hand van beleidstheorieën. Vanuit dergelijke beleidstheorieën wordt bedacht welke maatregelen en middelen nodig zijn ter bereiking van de gewenste doelen. 55

Van Mierlo geeft in zijn Maastrichtse oratie onder de titel 'De wereld gaat aan beleid ten onder' aan dat er veel beleid mis gaat. Hij biedt de nodige voorbeelden van falend beleid. ${ }^{6} 6 \mathrm{Hij}$ noemt als oorzaken, los ervan dat er teveel beleid wordt gevoerd: kennislacunes, falende beleidstheorieën, vooringenomenheid ter oplossing van cognitieve dissonantie57, een inadequate sturingsfilosofie. Hoewel men in abstracto weet dat de maakbaarheid van de samenleving beperkt is, gedragen naar zijn oordeel beleidsmakers zich als politieke ingenieurs die kant en klare keukentafeloplossingen bedenken. De sturing van de samenleving is top-down. Men maakt daarbij gebruik van rudimentaire theorieën, er is sprake van overschatting van beschikbare kennis en weinig neiging tot bijstelling van die kennis. Daarvan biedt collega Saskia Klosse een voorbeeld in haar oratie. Op het terrein van de sociale zekerheid was gekozen voor financiële prikkels om diverse betrokkenen uit de WAO te houden. Hoewel bleek dat die prikkels maar beperkt werkten, werd het beleidsfalen aangepakt door nieuwe specifieke wetten op te stellen om de gaten te dichten, met behoud van de gekozen theorie. 58

Het is ook niet makkelijk. Men moet causale wetenschappelijke verbanden in finale beleidstheorieën zien om te zetten. Ik geef een voorbeeld.

55 Het zijn de ambtenaren die dat werk moeten doen. Dat is de klassieke functie van de bureaucratie: de politiek geeft de motieven, de bureaucratie levert vervolgens de gronden en de kennis voor beleid.

56 Van Mierlo, 200o, p.28/29. Een recent voorbeeld biedt de commissie Blok over het integratiebeleid: waar integratie succesvol was, was dat niet het gevolg van gevoerd beleid (Bruggen bouwen, Den Haag, 2004, p. 106). Overigens relativeerde R.S. Gowricharn deze conclusie (Openbaar Bestuur, april 2004, p. 2-6).

57 Cognitieve dissonantie, ofwel het zien van tegenstrijdige feiten, wordt onaangenaam gevonden en mensen reduceren dat door ontkenning of door 'boetsering' van feiten.

58 Zo ontstaat een cumulatie van wetgeving. Ook Geelhoed wees, in een interview dat ik met hem had, op de vloed van wetgeving die het gevolg was van onvoldoende kennis van de werking van de wet en dus van tegenvallende beleidsopbrengsten. Zie ‘Het meesterschap...., p. 40; zie ook Publiek Management, december 2003, p.25 
De WRR verklaart de dreigende teloorgang van de rechtsstaat uit de groeiende hoeveelheid wetten die leidt tot onkenbaarheid, tegenstrijdigheid en gedogen.59 Achter die groei ziet de Raad maatschappelijke processen van individualisering en 'infantilisering' (de zeurende burger), en politieke processen van een overspannen verzorgingsstaat, van dienstverlening op maat, en internationalisering. De finale beleidstheorie die de Raad vervolgens hanteert is grofweg: meer handhaving en wetten die slechts globale normen kennen om zo ruimte te bieden, fricties te vermijden en tot minder regels te komen. Vooral op die beleidstheorie valt het nodige aan te merken: ze sluit slechts deels aan op de analyse (namelijk alleen qua handhaving), maar het is vooral de vraag of algemene regels tot minder regels en meer ruimte leiden. Mijn veronderstelling is dat a. globale regels leiden tot een uitvoerige nadere en gedetailleerde regelgeving bij uitvoeringsorganen (ter reductie van onzekerheid, bevordering van gelijkheid en vermijding van onzekere rechterlijke uitspraken), b. het bedrijfsleven tot nadere normen gaat komen, c. door de ruimte maatschappelijke machten en onwenselijk geachte situaties ontstaan want er zijn er die de ruimte misbruiken, waarop met regelgeving zal worden gereageerd, $d$. de overheid zal willen weten hoe met de vrijheid wordt omgegaan en dus meer toezicht gaat houden met alle regels van dien. Verder zal in geval van globale normen de rechter meer ingeschakeld worden door maatschappelijke actoren en dat kan tot gevolg hebben dat ten behoeve van de rechtszekerheid de rechterlijke macht tot een soort codificatie van beslissingen komt, tot nieuwe meer specifieke normen dus. Ruimte leidt tot regels, zou mijn beleidstheorie zijn. Kortom: de overgang van een causaal verband naar een finale beleidstheorie is niet zo gemakkelijk, vergt de nodige empirische kennis.

Gebrek aan kennis en aan beleidstheorieën acht van Mierlo de oorzaak van het gesignaleerde probleem van falend beleid. $60 \mathrm{lk}$ meen dat er een achterliggende factor is die deels kan verklaren waarom het gaat

59 WRR rapport 63

60 Met de relativering dat kennis beperkt en voorlopig is en dat sturing haar beperkingen kent- ik wees op de kloof tussen de wet in wording en de wet in werking. Volgens DHV (2002) draagt ook de ontoegankelijkheid van de regelgeving bij aan de problemen. Dat zou moeten leiden tot een aanvullende aanpak ten opzichte van de in $\mathrm{H} .6$ gedane voorstellen. 
zoals het gaat. Daarvoor biedt het model van de vier rationaliteiten van Snellen het aanknopingspunt. Hij wees op de spanning tussen de verschillende rationaliteiten die in een wet (maar ook in beleid) besloten ligt: de politieke, de economische, de juridische en de wetenschappelijke. Ik noemde ze al. Die factor is dat de politieke rationaliteit doorslaggevend is ten opzichte van de andere (beleid en wet worden immers uiteindelijk in de politieke arena vastgesteld) en enkele effecten heeft op de vorming van beleid en wetgeving.

\subsection{De invloed van de politieke rationaliteit}

Een eerste element hier van belang is de snelheid die gewenst wordt bij het ontwerpen en verwerkelijken van beleid en wetgeving:

- een regeerakkoord dat tevens een basis voor een wetgevingsprogramma vormt, moet snel worden opgesteld,

- een kabinet en zijn ministers willen een eigen gezicht laten zien en dat moet binnen vier jaar gelukt zijn,

- en er moet daarnaast snel ingespeeld worden op de emoties en problemen in de samenleving. ${ }^{61}$

Nu leidt traagheid niet noodzakelijk tot kwaliteit, maar voor inzicht in de werking van een wetsvoorstel en voor studie naar de verhouding tot andere regels is tijd nodig. Uitzoeken wat nu werkelijk het probleem is, althans welke perspectieven daarop bestaan, hoe het veld eruit ziet en welke posities worden ingenomen ten aanzien van probleem en oplossing, kost de nodige tijd. 62

Het nieuwe beleid moet vervolgens ingevoerd worden in bestaande complexen (instituties, routines, informatiesystemen). De bij de uitvoering, handhaving en naleving betrokken diensten, organen en bedrijven hebben tijd nodig zich aan te passen aan nieuw beleid en nieuwe regels. Patronen, instituties, werkwijzen veranderen langzaam. Snelle en zichtbare resultaten worden echter gewenst.

61 'De politiek lijdt aan hyperventilatie en bij een beetje tegenwind moet alles anders' (de Onderwijsraad in NRC13/14-3-04, p. 34). Zie ook het jaarverslag 2003 van de Raad van State. Niessen evenwel: een perfecte wet die te laat komt, is een slechte wet (RegelMaat, p. 89).

62 Klinkers wijst erop dat politici denken in termen van oplossingen, niet in probleemdiagnoses (in: Vaarwel volksvertegenwoordiging, Openbaar bestuur, maart 2004, p. 13-16). 
Dus komen er nieuwe beleidsmaatregelen. Dat geeft fricties. 63 Het gaat hier niet om goed of slecht- het gaat om een onvermijdelijke botsing van op zich heel redelijke invalshoeken.

Een tweede element is de werking van de ministeriële verantwoordelijkheid. Bewindslieden worden op hun beleid aangesproken, en dat is inherent aan ons stelsel. Zij zijn bevoegd en moeten daarom verantwoording afleggen: inlichtingen geven, beleid rechtvaardigen en besluiten motiveren. Maar ondanks alle wijze staatsrechtelijke beschouwingen daarover, lijkt de politieke verantwoordelijkheid te zijn gaan inhouden dat bewindslieden geen fouten meer mogen maken, dat altijd de $100 \%$ juiste oplossing voor problemen moet bestaan. 64 Toerekenen is aanrekenen en afrekenen geworden. 65 Broeksteeg spreekt over een verschuiving van politieke risicoaansprakelijkheid (het ambt) naar schuldaansprakelijkheid (de persoon). ${ }^{66}$ Een dergelijke beleving van de ministeriële verantwoordelijkheid leidt tot grootspraak en angst. Beide leiden tot pogingen greep op de uitvoering te hebben. Omdat de greep op de uitvoering al niet groot is en verminderd is vanwege de scheiding tussen beleid en uitvoering (om, o paradox, de last van de ministeriële verantwoordelijkheid te verlichten), ontstaat de neiging voortdurende en uitvoerige rapportages van de uitvoering en andere adressaten van regelgeving te vragen, toezicht op toezicht te stapelen en te komen tot aanscherping en detaillering van regels. 67

63 Als op een terrein zich veel beleidswijzigingen voordoen, leidt dat tot de nodige ergernis en weerstand. "Een school hoort resistent te zijn tegen overheidsplannen”, aldus schooldirecteur en oud-kamerlid Kars Veling (NRC 13/14-3-04, p. 33).

64 Beleid is vaak een experiment. Naar mijn oordeel zou het de politiek en de geloofwaardigheid ervan ten goede komen indien bewindslieden dat experimentele karakter vooraf, bij de behandeling van de plannen, benadrukken. Dan hoeven zij ook minder 'sorry' te zeggen. Zie ook Vos en van Doorn, 2004.

65 Zie Niessen, p. 8, en L. Verhey, p. 35

66 diss. 2004, p. 357/358. De veronderstelling is gewettigd dat het verkleinen van de kloof tussen politici en burgers een negatief effect zal hebben op de algemeenheid en de stabiliteit van de wetgeving.

67 Zo na de rampen van Enschede en Volendam (zie Verhey, 2001). Men kan zeggen dat op zich redelijke eisen als transparantie en verantwoording van publieke middelen leiden tot administratieve of bureaucratische eisen. De kwestie is vooral of er sprake is van overdaad en wat men met de informatie kan doen of doet. 
Recent wees de vice-voorzitter van de Raad van State op dit verschijnsel. 68

Ten derde. Beleid en wetgeving komen tot stand in een politieke en beleidsmatige arena, maar zij moeten worden uitgevoerd in andere arena's. Het oog van politici is in hoge mate gericht op wat er in het parlement wordt gedacht. Uitvoeringsproblemen worden, zo is al lang bekend, makkelijk gebagatelliseerd. 69 De probleemverplaatsende functie van beleid en wetgeving speelt hier tevens een rol. Vanuit een bezuinigingsstreven is het plezierig de kosten van centraal beleid elders te alloceren.

In dit verband heeft het primaat van de politieke rationaliteit nog een ander effect. Als een koers is uitgezet en beleid bepaald in de politieke arena, worden feiten in dat licht geplaatst. Onwelgevallige kennis wordt gepolijst, zou men kunnen zeggen. Dit is de opheffing van de cognitieve dissonantie waar Van Mierlo over sprak. Dat speelt ook op het ambtelijke niveau. De bureaucratie levert de vakkennis aan de bewindslieden. Door de politieke rationaliteit is de kans groot dat de ambtelijke voorbereiders van beleid en wetgeving naar boven kijken (dat horen zij ook te doen) en minder naar 'beneden'. Zij modelleren gegevens naar de gewenste kijk op het probleem. Men ziet dat in het relatief matige gebruik van de resultaten van evaluatieonderzoek70, men ziet het in de reactie op de adviezen van de Raad van State, zoals uit een nog lopend onderzoek van de Maastrichtse collega's als beeld naar voren komt. De regering neemt opmerkingen van de Raad betreffende de beleidsmatige kwaliteit, de doeltreffendheid en doelmatigheid in het bijzonder, niet of nauwelijks over. De regering weerspreekt ze of past slechts enigszins de toelichting aan. $7^{11}$

68 Jaarverslag 2003, p. 21

69 Een voorbeeld biedt de Wet medezeggenschap cliënten zorginstellingen (Wmcz), waar de verwachting was dat deze geen noemenswaardige kosten zou meebrengen, terwijl bij de uitvoering bleek dat voor een goede uitvoering dat wel zo was. J. de Savornin Lohman c.s., p. 63. Zie in algemene zin het Rapport van de Algemene Rekenkamer, 2003.

70 Veerman, 1991; naast de reductie van de cognitieve dissonantie (en de tegenzin tegen erkenning van fouten) speelt de agendabouw daarbij een rol: het probleem moet weer opnieuw de politieke agenda zien te bereiken.

71 Zie ook het onderzoek van Eijlander c.s. over de invloed van het Regeerakkoord. Een aanvullende hypothese is dat de adviezen van de Raad beleidstheoretisch niet erg rijk zijn, zoals af te leiden is uit het Maastrichts onderzoek en dat van Dorbeck-Jung: gebaseerd op intuïtie en 'common sense'. Ook draagt bij dat 's Raads opmerkingen vaak in vragende vorm zijn geformuleerd. De beleidsanalytische toets is zo analytisch nog niet. 
Overigens kan er een andere, bijna tegenovergestelde, kracht spelen die stimulerend werkt op het filteren van informatie. Die kracht is dat ambtenaren technisch specialisten zijn met een eenzijdige kijk, dan wel dat beleidsambtenaren vaak vaste contacten hebben in het veld en dat hun werk, kennispositie en invloed, hun aanzien mede daarvan afhankelijk is. Waar dat veld belang kan hebben bij de bestaande arrangementen, is daar een potentieel tegenwicht tegen politieke veranderingen. Dat hoeft geen ambtelijke kwaadwillendheid te zijn. Het kan een kwestie van 'bias' zijn.72

Ik hecht er aan, ter afsluiting, op te merken dat de politieke rationaliteit er is en dat die noodzakelijk is. Zonder zou het moeilijk zijn te regeren, een beleid te maken, een richting te bepalen en knopen door te hakken. Zonder is er onvoldoende controle op de regering. De politieke rationaliteit is bepalend, zo is de essentie van ons stelsel. Maar dat wil niet zeggen dat de politieke rationaliteit geen problemen in zich bergt.

De conclusie is dat problemen met wetgeving verband houden met een gebrek aan kennis en goede beleidstheorieën en dat de politieke rationaliteit daarop inspeelt: die kleurt de betekenis van de juridische en wetenschappelijke rationaliteit en beïnvloedt daarmee de instrumentele kwaliteit van wetgeving.

72 In de literatuur zijn er eveneens geluiden dat ambtenaren hun machtsbasis, nl. kennis, gebruiken om de politiek te manipuleren en eigen doelen na te streven (Andriessen, p.49 e.v.). 't Hart ziet vooral loyale ambtenaren (o.a. Trouw,12-3-04). 


\section{De barrière van het wetgevingskwaliteits- beleid}

\subsection{Het wetgevingskwaliteitsbeleid}

De overheid voert sinds 1951 een wetgevingskwaliteitsbeleid.73 Eerst gebeurde dat via wetstechnische richtlijnen, later via diverse sporen. Ik geef kort een beeld van het huidige kwaliteitsbeleid, met in het achterhoofd de diverse elementen van het zogenaamde totaal kwaliteitsbeheer.74

Er zijn de genoemde kwaliteitseisen, daaraan wordt getoetst binnen departementen en door Justitie, er zijn professionele wetgevingsjuristen, bij de meeste departementen is de wetgevende functie georganiseerd in centrale wetgevingsafdelingen, en er wordt geïnves-teerd in de competenties van het wetgevend personeel via de Academie voor Wetgeving, het Kenniscentrum Europees Recht en het Kenniscentrum Wetgeving.

Het management van de mensen en de organisatorische condities zijn inmiddels redelijk geborgd. Op het terrein van het management van wetgevingsprocessen gebeurt de laatste tijd het nodige75. Steeds meer

73 De eerste stap vormden de richtlijnen voor de wetgevingstechniek: 21 voornamelijk taalkundige adviezen.

74 Vanuit een kwaliteitsperspectief kan men de volgende indeling maken voor een kwaliteitsbeleid:

- De externe omgeving van de wet (het staatkundig bestel, de maatschappelijke situatie)

- De aard van het product 'wet', amvb e.d.

- Het concept van de kwaliteitseisen, alsmede de kwaliteitseisen zelf.

- Het wetgevingsproces:

institutionele voorzieningen

- organisatie bij de actoren zoals een centrale wetgevingsorganisatie,

- toetsende organen zoals WKB

- werving, opleiding, gereedschapskist, management van processen e.d.

procesmatige voorzieningen

- startnotitie, benchmarking, betrokkenheid van externen, prognostische instrumenten, evaluatie, waarin begrepen een bijzondere aandacht voor

- de relatie met externen.

75 Er zijn wel meer elementen te noemen, zoals de interdepartementale projecten waarbij wetgevingscomplexen tege het licht worden gehouden. In Brussel is zo'n wetgevingskwaliteitsbeleid nog in ontwikkeling. 
departementen kennen protocollen aan de hand waarvan men het proces van de voorbereiding van wetgeving beter kan vorm geven. Er worden waar nodig een bedrijfseffectentoets, een milieutoets en een nalevingstoets gehouden 76 , terwijl ook op administratieve lasten wordt getoetst. Nieuw zijn de zogenaamde 'quick scans', waarbij in een vroeg stadium doel en instrumentarium van een beleids- annex wetgevingstraject worden bekeken.77 Recent is er ook meer aandacht voor de aard van de wetgeving, zoals de voorkeur voor doelvoorschriften boven middelvoorschriften.

De politiek zorgt idealiter voor de motieven voor regulering (de reden en de richting van het beleid), terwijl de ambtenarij werkt aan de gronden van een regeling, de kennis over de maatschappelijke en juridische mogelijkheden en onmogelijkheden. Het wetgevingskwaliteitsbeleid heeft als functie zo goed mogelijke wetgeving te verzorgen. Dat is gelet op de kwaliteitseisen, wetgeving die werkt. Dat houdt in dat het wetgevingskwaliteitsbeleid een, let wel: door het kabinet gewenste en georganiseerde, juridische en wetenschappelijke barrière vormt tegenover de politieke rationaliteit.

\subsection{Waarom die barrière niet volmaakt werkt}

Gelet op de kritiek op wetgeving werkt de barrière van het wetgevingskwaliteitsbeleid kennelijk onvoldoende. Dat houdt verband met de politieke rationaliteit. Maar er zijn ook enkele meer immanente redenen, die samenhangen met de organisatie van het wetgevingskwaliteitsbeleid en de aard van de kwaliteitseisen. 78

76 Meer algemeen geldt dat het belangrijk is dat voortschrijdend inzicht ook leidt tot terugkoppeling in het voorbereidingsproces en tot bijstelling in doel en/of instrumentarium. Dat gebeurt niet vanzelf, toetsen zijn eenmalig. In het Protocol van SZW (voor de aanpak van beleids-/wetgevingsprojecten) wordt uitdrukkelijk wel op het belang van terugkoppeling van nieuwe kennis gewezen.

77 Er zijn wel meer elementen te noemen, zoals de interdepartementale projecten waarbij wetgevingscomplexen tege het licht worden gehouden. In Brussel is zo'n wetgevingskwaliteitsbeleid nog in ontwikkeling.

78 Voor de Europese regelgeving lijkt eenzelfde situatie te bestaan: een sterke politieke rationaliteit (positie Commissie, compromiskarakter regelgeving, gericht op eigen besluitvorming en niet op de uitvoering), waartegen een ontluikend kwaliteitsbeleid nog niet een voldoende barrière kan bieden. 
a. De organisatie

- De overheid heeft het wetgevingskwaliteitsbeleid vooral ambtelijk georganiseerd79 en heeft daarbinnen die zorg eigenlijk aan wetgevingsjuristen toebedeeld. Op dit punt speelt de genoemde relatie tussen wet en beleid een rol.

- Het beleid is breder en meer omvattend dan de onderdelen die in de wetgeving zijn vastgelegd. Ik beschreef $u$ dat voor de uitvoering van de wet eveneens financiële middelen en andere beleidsmaatregelen nodig zijn.80 Alleen het wetsvoorstel sec wordt echter getoetst, niet het (flankerende) beleid. Voor het beleid is een dergelijke structuur van kwaliteitsbeheer niet of nauwelijks voorhanden. 81

- De kwaliteitseisen zijn geformuleerd als kwaliteitseisen voor de wetgeving, al zijn zij grotendeels van beleidsmatige aard. Maar de wetgevingsjuristen schrijven en toetsen. Die zijn minder geverseerd in bestuurskundige en beleidsmatige zaken. ${ }^{82}$ De professionalisering van de wetgevingsjurist, de versterking van de juridische expertise door opleiding en organisatie, versterkt in feite de scheiding tussen beleid en wetgeving.

Waar bovendien de beleidsmensen met de buitenwereld praten over de beleidsmatige aspecten van een wet, wordt de rol van wetgevingsjuristen in de toetsing van de kwaliteitseisen een margina-

79 De minister van Justitie heeft een algemene verantwoordelijkheid voor de kwaliteit van wetgeving. Gelet op de verwevenheid van beleid en wetgeving betreedt hij, als hij commentaar heeft, al gauw het beleidsterrein van zijn collega's. Hij moet dus 'prudent' omgaan met de vervulling van zijn verantwoordelijkheid.

80 En daar zit vaak het probleem.

81 Met uitzondering van de genoemde VBTB-operatie (Van beleidsbegroting tot beleidsverantwoording- specifieke doelen moeten worden omschreven en de middelen daartoe aangegeven. Gegeven de specificiteit die gewenst wordt, leidt deze operatie waarschijnlijk tot juist (niet gewenste) gedetailleerde wetgeving. Er is wel controle achteraf georganiseerd, via de Algemene Rekenkamer.

82 De wetstechnische en juridische kwaliteit van wetten is redelijk geborgd met professionele wetgevingsjuristen, een toets door Justitie en door de Raad van State, en een wetgevingsproces dat vaak begeleid wordt door een kritische rechtswetenschap. De juridische kwaliteitseisen zijn ook relatief hard. 
le. 83 De genoemde kenniskloof tussen beleidsidee en werkelijkheid kunnen zij moeilijk dichten, de 'klanten' blijven voor hen grotendeels buiten beeld .84

- De kwaliteitszorg is primair is gericht op de afzonderlijke wet. Dat heeft tot gevolg dat het wetgevingskwaliteitsbeleid minder zicht heeft op het mesoniveau (ondanks de eisen van de onderlinge afstemming en oog voor neveneffecten). 85 Het macroniveau van het totaal van de wetgeving blijft (ondanks het noodzaakvereiste) buiten beeld; zoals de vertaling van doelen op macroniveau in maatregelen op microniveau een probleem is, zo is omgekeerd het effect van een afzonderlijke wet op het totaal van de wetgeving moeilijk te bepalen.

b. De kwaliteitseisen

Ook de aard van de kwaliteitseisen maakt dat ze geen barrière kunnen vormen, zoals ik hiervoor al liet zien.

- De kwaliteitseisen zijn in hun toepassing vaag, soms onderling tegenstrijdig en de onderlinge relatie hangt af van de functie die een wet moet gaan vervullen.

- De kwaliteitseisen betekenen voor een belangrijk deel een schot in het duister: doelmatigheid, doeltreffendheid, handhaafbaarheid, uitvoerbaarheid van een wetsvoorstel betreffen prognoses. Of een wet eraan voldoet, zal in de praktijk blijken-soms na jaren. Dat levert geen sterke argumenten op in een discussie over noodzaak en inhoud.

- De kwaliteitseisen verhullen de uiteenlopende belangen en rationaliteiten.

Het wetgevingskwaliteitsbeleid kan vooral zorg dragen voor de juridische kwaliteit, en dat blijkt niet voldoende te zijn.

83 Zie Stoter en Huls, p. 15. Overigens bestaat in Nederland wel een traditie van overleg met betrokkenen met het oog op beleid en wetgeving. Veelal wordt gesproken met belangenbehartigers en bestuurders, niet met 'de zwoegers op het veld' en met de georganiseerden. Beide kunnen leiden tot eenzijdige en onvolkomen informatie.

84 Dat geldt overigens niet in alle situaties op alle departementen.

85 Wel vinden via interdepartementale projecten (bijvoorbeeld tot voor kort in het kader van de MDW-operatie) reparaties achteraf plaats. 


\section{Kwaliteitsimpulsen en onderzoek}

\subsection{De wet als zinsbegoochelingstoestel}

De wet is een zinsbegoochelingstoestel. De geschreven wet is een prachtuitvinding, die zekerheid en voorspelbaarheid schept en daardoor samenleven en maatschappelijke ontwikkeling mogelijk maakt. Met regels en wetten moet en wil de overheid sturen, maar de mogelijkheden zijn beperkt.

De wet begoochelt de zinnen waar mensen graag en snel om een 'wet' vragen om een probleem aan te laten pakken of hun opvattingen vast te leggen, terwijl over de zin ervan twijfel kan bestaan. De wet is een vat vol paradoxen waar zij ruimte biedt door regels te stellen, waar zij bescherming biedt en tegelijkertijd knellend kan zijn, waar zij de actualiteit en de continuïteit moet dienen.

De wet is een zinsbegoochelingstoestel waar de uiteenlopende betrokkenen hun betekenis aan de wet geven, aan de zin en de kwaliteit ervan. Als de wet er is, weet je nog niet hoe zij zal werken; in de samenleving kan zij van kleur verschieten. Het oordeel over de kwaliteit van wetten varieert naar niveau (de makers en de gebruikers) en naar functie, naar rol en positie.

Het klassieke wetsbegrip begoochelt de zinnen: de rechtsstaat zou gered worden als we teruggaan naar het wetsbegrip van de Verlichting, waarbij openbare en algemene normen voor rechtszekerheid, rechtsgelijkheid en vrijheid zorgen. Dat wetsbegrip is echter altijd een begrip gebleven. ${ }^{86}$ Via de wet wordt recht geschapen, maar sommigen willen

86 In de praktijk werd en wordt de formele wet gebruikt voor allerlei maatregelen. Ik heb een jaarboek met Staatsbladen uit de 19de eeuw genomen, van na 1848 en van gemiddelde dikte: 1855 . Van de 145 wetten die dat jaar werden gepubliceerd, betroffen er 50 naturalisaties, 24 gemeentelijke herindelingen, 22 de begroting, waren er 21 financieel getint (belasting e.d.), bevatten enkele onteigeningsbepalingen en enkele andere ambtelijke rechtspositiebepalingen. Er zijn twee staatkundige wetten, te weten die tot regeling en beperking der uitoefening van het regt van vereeniging en vergadering (wet van 22-41855) en die houdende regeling der verantwoordelijkheid van de Hoofden der Ministeriële Departementen (eveneens van 22-4-1855). De Wet van 18-12-1855 tot aanmoediging van den invoer van granen en andere levensmiddelen bevat een schorsing van heffingen; de wet van 9 juli 1855 verklaart een oudere wet van toepassing op fabrikanten en verkopers van 'buskruid, vuurwerk of schietkatoen' en geeft de gemeenten de vrijheid bepalingen vast te stellen over de opslag van buskruit. Ze zijn niet alle even verheven. 
dat met hoofdletters kunnen schrijven. ${ }^{86 a}$

Ik verbond de problemen met wetgeving aan relatief gebrekkige kennis van de werkelijkheid waarin die wet moet werken en daarmee aan gebrekkige beleidstheorieën, waarbij de politieke rationaliteit als een soort multiplier werkt.

Al is 'kennis' voorlopig en beperkt, al zijn er belemmeringen in het vergaren en gebruiken van beschikbare kennis, mijn credo is dat meer kennis kan helpen om tot betere beleidstheorieën te komen en de brug te slaan tussen slagzinnen en beleid, evenals tussen de wet in wording en de wet in werking. De belangen kunnen beter bepaald en afgewogen worden, naarmate er meer kennis beschikbaar is over de context waarin de wet moet gaan werken. Ik veronderstel dat dat geen zinsbegoocheling is.

\subsection{Kwaliteitsimpulsen en onderzoek}

Vanuit dit credo doe ik enkele voorstellen voor studie en onderzoek op het vlak van wetgeving. ${ }^{87}$ Het gaat in essentie natuurlijk om de politieke praktijk, om beter beleid en een beter beleidskwaliteitsbeleid. Maar mijn invalshoek is nu eenmaal de wetgeving en haar kwaliteit.

$\mathrm{Nu}$ onderneemt de sector wetgevingskwaliteitsbeleid van het ministerie van Justitie al veel ter bevordering van de wetgevingskwaliteit. Tot die activiteiten horen onderzoek en instrumentontwikkeling. Mijn voorstellen zijn dus aanvullend en deels overlappend ten opzichte van het lopende kwaliteitsbeleid.

Ik merk daarbij nog het volgende op. In de eerste plaats zijn de totstandkoming en de werking van wetgeving niet zozeer juridisch van aard. Voor inzicht in het verschijnsel wetgeving, voor wat betreft de inhoud, het proces en de werking, moeten wij juristen te rade gaan bij de diverse sociale wetenschappen. In de tweede plaats is in het wetgevingsproces het verschaffen van kennis een in Weberiaanse zin typisch

86 aHet wetgevingscabaret van het ministerie van Justitie heeft in het Volkslied voor de

Wetgevingsjurist korte metten met deze opvatting gemaakt:

Regelzucht moet aan banden

Het Paradijs breekt dan aan

En de wet die dat gaat regelen

Die komt er morgen aan

87 Deze zullen leiden tot een meer uitgewerkt onderzoeksprogramma. 
bureaucratische taak. Mijn voorstellen zullen dus een nogal bureaucratisch karakter hebben, in de goede zin van het woord.

De voorstellen die ik wil doen voor verdere studie en thematisch onderzoek $^{88}$, hebben in hoofdzaak betrekking op drie elementen.

a. Het verkleinen van de kloof tussen de wet in wording en de wet in werking en het verruimen van het klantperspectief: 89

- wij weten nog relatief weing van de feitelijke effecten van verschillende typen normen (zoals open-gesloten), van de effecten van verschillende juridische constructies zoals vergunningen, van de relatie tussen de aard van de norm en de aard van toezicht of handhaving;

- verder weten we wat meer, maar nog onvoldoende over de relatie tussen de betrokkenheid bij de voorbereiding en de werking van wetgeving alsmede naar de mogelijkheden en betekenis van de diverse vormen van onderhandelend bestuur; 90

- de kloof kan mogelijk verkleind worden door conceptwetsvoorstellen te publiceren op internet; monitoring en/of onderzoek naar de gevolgen daarvan is dan nodig;

- de kloof kan voorts mogelijk worden verkleind door de ontwikkeling van bijvoorbeeld Wetsbegrijpelijkheidstesten91 en, op collega Dick van den Bosch geïnspireerde, Objecttesten 92 en door elk wetsvoorstel van een

88 Evaluaties van afzonderlijke wetten leiden niet tot grote leereffecten, om reden van reductie van cognitieve dissonantie en agendabouw (de geëvalueerde wet moet op de agenda zien te komen). Evaluatie van diverse wetten op thematische vragen is waarschijnlijk vruchtbaarder.

89 Zoals gezegd, niet in de zin van instantbevrediging van wensen, maar uit oogpunt van afweging van baten en lasten en van werking van wetten.

90 Op dat terrein is overigens al veel studie verricht. Van Mierlo en van Gunsteren propageren minder sturing van boven af en meer netwerksturing. De overheid zou dan procesbewaker zijn. Daar is veel voor te zeggen, zij het dat de overheid moet zorgen dat zij haar rol als hoeder van het algemeen belang, hoe abstract ook, vervult.

91 Het verantwoordelijke departement stelt vragen aan een panel betrokkenen over een wetsvoorstel. Als bv. 40\% zakt, is sprake van een slechte wet.

92 Aan de hand van een object, bijvoorbeeld een winkel, wordt bezien welke regels al van toepassing zijn en hoe de ontworpen regeling daarmee interfereert. Overigens geldt dat omdat veel klachten specifiek zijn, deze klachten onderzocht kunnen worden en leiden tot een -hernieuwde-afweging tussen algemene baten en specieke lasten. 
invoeringsplan vergezeld te doen gaan;93: ook daarvoor is studie nodig naar de condities opdat dat idee niet de verdrietige weg van de verplichte voorspellingen zal gaan.

b. Het verbeteren van de kwaliteitseisen en verschaffen van beleidsmunitie aan wetgevingsjuristen 94 .

- De vraag wat een goede wet is, blijkt niet goed te beantwoorden en levert dus geen munitie voor het beleidsdebat. Mogelijk is het verstandiger criteria vast te stellen voor wat een slecht wetsvoorstel is95, door de positieve aandachtspunten aan te vullen met negatieve kwaliteitseisen (bijvoorbeeld: een wetsvoorstel zonder invoeringsplan is slecht en mag niet bij de Kamer worden ingediend)95a;

- Er bestaan beleidsanalytische instrumenten, zoals de kosten-batenanalyse en de Log Frame Analyse, die bruikbaar kunnen worden gemaakt voor wetgevingsjuristen zij kunnen dan mogelijk beter beleidsmatige vragen aan het beleid stellen.

- Onderzoek naar het -ambtelijk- gebruik van de gegevens verkregen uit administratieve informatieplichten.

c. Het versterken van de barrière van het wetgevingskwaliteitsbeleid. Ik doe daartoe drie voorstellen die nadere studie vergen:

- breng de prijs van het maken van regels in beeld.

- breng iets van de politieke rationaliteit in in het wetgevingskwaliteitsbeleid via

93 Samen met Kampfraath heb ik eerder betoogd dat elke wet gepaard dient te gaan met een invoeringsplan, een overzicht van zowel de directe als de structurele kosten van invoering en uitvoering (rapport Visitatiecommissie Wetgeving, bijlage 3) voor de overheid en de justitiabelen. In het kabinetsstandpunt “Handhaven op niveau” wordt een aanzet gegeven tot zo'n handhavingsplan (kamerstukken II, 1999-2000, 28600 VI, nr. 67, p. 5).

94 Het gaat om munitie. Waar wetgevingsjuristen onderdeel van een lange wetgevingsketen zijn en zeker niet de sterkste schakel daarin vormen, zou het van grootheidsfantasie getuigen te denken dat 'de redding van de kwaliteit van wetgeving' in termen van werking van hen moet komen.

95 Dat is, zo vermoed ik, geen kwestie van etikettering. Een slecht wetsvoorstel is makkelijker 'retourneerbaar' door de Kamer. Negatieve eisen zijn ook: niet in strijd met hoger recht, verbod van terugwerkende kracht.

95aEen aanzet hiertoe vindt men in de nota 'Bruikbare Rechtsorde', kamerstukken II, 20032004, 29279, nr. 9, p. 10-12. 
- een Comptabiliteitswet voor de wetgeving, waarbij de minister van Justitie een sterkere positie verwerft 96 en via

- een Wet op de wetgevingskwaliteit; dan hebben de Tweede Kamer en Eerste Kamer ook kwaliteitseisen. 97

Er is nog veel te doen.

96 Die gedachte is ooit door staatsraad Hoekstra uitgesproken.

97 Ook dergelijke voorstellen moeten overigens nog verder op nut en werking bekeken worden. 


\section{Dankwoord}

Geliefde en gewaardeerde toehoorders, ik verwacht niet dat ik uw zinnen begoocheld heb, maar ik ben verheugd dat u naar deze rede kwam luisteren -ik weet hoe ver het is.

Ik zal niet zeggen dat wetgeving mijn zinnen begoocheld heeft. Maar ik vind het mooi dat ik, naast mijn ambtelijke betrokkenheid bij de kwaliteit van wetgeving, aan deze Universiteit verder mag denken over en onderzoek doen naar wetgeving en de kwaliteit van wetgeving. Ik wil daarom de universiteit Maastricht en de faculteit der rechtsgeleerdheid zeer bedanken voor mijn benoeming en het in mij gestelde vertrouwen. Ik ben daarbij erg hartelijk ontvangen, zeker ook door de capaciteitsgroep Publiekrecht en in het bijzonder door Luc Verhey en Saskia Klosse. Het is een prettige bij het vak en bij elkaar betrokken capaciteitsgroep, heb ik gemerkt.

Hooggeachte Roes, ik heb beloofd je zo aan te spreken en ik doe dat graag. Je hebt je als directeur Wetgeving op Justitie, samen met de evenzeer hooggeachte Jan Tom Bos, ingespannen een leerstoel te scheppen over wetgeving en wetgevingskwaliteit om het debat erover aan te scherpen en het wetgevende werk te confronteren met de wetenschap. Het toont dat jullie niet bang zijn en ruimte willen geven. Ik hoop de brug tussen theorie en praktijk te kunnen slaan en die ruimte maximaal te benutten. Ik wil via jullie ook de minister van Justitie bedanken voor de ondersteuning van deze leerstoel.

Collega's en vrienden van de sector wetgevingskwaliteitsbeleid, van Justitie en van andere departementen. Wetgevingsjuristen hebben een zekere studieuze en kritische inslag. Zij zijn erg nodig, voor de rechtmatigheid der wetten, vanwege hun kritische zin en omdat zij voor een belangrijk deel het studiemateriaal voor de rechtswetenschap verzorgen. Ik hoop dat ik jullie de komende jaren mag inschakelen bij onderwijs en onderzoek. Van de collegae noem ik overigens Janneke Kramers, Sander Mul, Edward Vriends en Jacqueline Bonnes met name, om hen te bedanken voor hun opmerkingen bij eerdere versies van deze oratie. 
Lieve Akke, ik doe jou het meest een plezier als ik alle juristen en beleidsmakers die deze oratie zullen zien of horen lezen (saluut!) doe weten dat een geweten een cruciale voorwaarde is voor een beschaafde omgang met wetgeving. Dat geweten wordt gevormd in de eerste kinderjaren. Daar begint het wetgevingskwaliteitsbeleid. $9^{8}$ Bij dezen doe ik dat, met instemming en met liefde. Ik wil daarbij opmerken dat 'een beschaafde omgang' voor jou zeker niet betekent: blinde gehoorzaamheid aan de wet. Regels zijn er om het leven met anderen mogelijk en wat makkelijker te maken.

Dames en heren studenten, ik heb nog geen student gezien. Dat komt niet omdat ik deze oratie te vroeg houdt, maar omdat dit vak een keuzevak is in de Mastersopleiding, en die moet nog komen. Ik wacht met smart op jullie- om dan met jullie de wording en de werking van wetten concreet te onderzoeken en te ondervinden dat een wet echt een zinsbegoochelingtoestel is.

Ik heb gezegd.

98 Een dergelijke fundamentele inzet van het wetgevingskwaliteitsbeleid verdient overigens nadere overweging. 


\section{Geraadpleegde literatuur}

M. Andriessen, Bureaucratie aan banden - perspectieven voor een nieuwe dereguleringsoperatie, Teldersstichting-geschrift 96, Den Haag, 2004

L.J.M., d'Anjou en J.J. van der Kaaden, Wetgeving en sociale wetenschappen, Justitiële Verkenningen, 1978/1, p. 4-25.

L.J.M. d'Anjou, Actoren en factoren in het wetgevingsproces, diss. RUL, Deventer, 1986

B. Baarsma, C. Koopmans, J. Mulder, M. de Nooij, C. Zijderveld, Goed(koop) geregeld: Een kosten-batenanalyse van wetgeving en zelfregulering, SEO, Amsterdam, 2004

C.G. Bakker, E. Steenbergen-Meertens, Integrale kwaliteitsszorg en verbetermanagement, Groningen, 2002-2

F.A. Bentlage, J.B. Boelens, J.A.M. Kip, De excellente overheidsorganisatie, Deventer, 1998

R. van den Berg, Vormen van begrip van wet en wetgeving, diss. Tilburg, 2003

G.F. Bögels, Verbindingslijnen tussen babyobservatie en psychoanalytische behandeling, in: A. de Bruijne en W. Heuves, Bij nader inzien- over kijken en psychoanalyse, p. 21-43, Amsterdam, 2001

Pauline de Bok- De jungle van de commerciële zorg, VN, 19 juli 2003, p. 12-14

J.M. Bonnes, Tien jaar na Voortvarend wetgeven: verbeter Haagse wetgevingsprocedures opnieuw, RegelMaat, 2004-1, p. 17 - 27

D.P. van den Bosch, Vorm of Vent? Structuur of boodschap?, in Symposium 'De verhouding tussen domein- en probleemgerelateerde wetgeving', Den Haag, Ministerie van Justitie/ DW, 2002, p. 27- 38 
J.L.W. Broeksteeg, Verantwoordelijkheid en aansprakelijkheid in het staatsrecht, diss. RUG, Deventer , 2004

Consumentenbond, Zwartboek 'Vastgelopen in de zorg', december 2002

C. Damaisjah en E. de Kleuver, Nederland voelt zich veiliger- de Politiemonitor bevolking 2003. Algemeen Politieblad, 2003/15, p. 10- 13

C.A. Davids, Aristocraten en juristen, financiers en feministen: het beschavingsoffensief van de dierenbeschermers in Nederland voor de Eerste Wereldoorlog, Volkskundig Bulletin 13, p. 157-200.

DHV, Knelpuntenonderzoek veiligheidswetgeving, Amersfoort (DHV), 2002

P.A. Donker van Heel, F. van Zutphen, C.P.A. Zoon, Regeldruk voor OCWinstellingen, Rotterdam (ECORYS-NEI), 2004

B.R. Dorbeck-Jung, Zicht op wetgevingskwaliteit. RegelMaat, 2003-4, p. $131-142$

B.R. Dorbeck-Jung, Beelden over de wetgevingsadvisering van de Raad van State, Den Haag, 2003

Ph. Eijlander, W. Voermans, Evaluatie Regeerakkoord 1998 vanuit wetgevingsperspectief, Tilburg, 2000

EIM, Knelpunten voor ondernemerschap in Nederland, 2002

Lon L. Fuller, The morality of law, Yale Un. Press, 1969-4

M. van Ginkel e.a., Regeldrukte, ministerie van EZ, Den Haag, 2003

H. van Gunsteren, Woordenboek voor verwarde politici, Amsterdam, 2003

H.Hijmans, Wetgevingskwaliteit in de Europese Unie en de rol van de Europese rechter, RegelMaat, 2003/1, p. 15- 28 
J. van der Hoeven, De drie dimensies van het bestuursrecht, Alphen a/d Rijn, 1989

N.J.H. Huls, mmv H. Ackermann en E. van Ruyven, Onderhandelend wetgeven in de praktijk, Amsterdam, 1998

P. Jonkers, Diskwalificatie van wetgeving, diss. Nijmegen, Amsterdam, 2003

D.R.Kloosterman, H.B.Winter,F.M. Noordam, J.de Ridder, In zelfstandigheid geregeld- onderzoek naar de feitelijke omvang en kwaliteit van regelgeving door zelfstandige bestuursorganen, RUG, maart 2002.

S. Klosse, Moderne sociale zekerheid: efficiency met behoud van fundamentele waarden, oratie Maastricht, Den Haag 2003

D. Kraaijpoel, De nieuwe salon, Academie Minerva Pers, 1990-3

J.G.A. van Mierlo, De wereld gaat aan beleid ten onder, oratie Maastricht, Maastricht 2000

S.F. Moore, Recht en sociale verandering: de rol van het 'semi-autonoom sociaal veld' bij de sociale werking van het recht, in: Een kennismaking met de rechtssociologie en rechtsantropologie, p. 309- 337, Ars Aequi Libri, 1992-2

E.C. Mudde, Ziek in de zin der wet, diss. UvA, Den Haag 1995

A.F.M. Nijsen, Onkruid vergaat niet: geldt dat ook voor administratieve lasten?, RegelMaat, 2004-2, p. 48-58

S.C. Pey, B.G. Westerink, H.B. Winter, Juridische kwaliteitszorg, Deventer, 2003-2

J.E.M. Polak, Bestuursrechtelijke kanttekeningen bij de toekomst van de nationale rechtsstaat, NTB, 2003/6, p. 168-172

Raad van State, Symposium Kwaliteit van de Europese regels, Den Haag 2001, met bijdragen van J.P.H. Donner, L.J. Brinkhorst, R.H. Lauwaars, L.A.D.Keus en T. Koopmans 
Raad van State, Jaarverslag 2003, Den Haag 2004

Rijksuniversiteit Groningen, Alle regels tellen, 2004 (nog niet gepubliceerd)

U. Rosenthal, Bureaupolitiek en bureaupolitisme, oratie Leiden, Alphen ad Rijn, 1988

(J. de Savornin Lohman e.a., Evaluatie Wet medezeggenschap cliëntenzorginstellingen (WMCZ), Den Haag (ZON-MW), 2000

M. van Schendelen, De brave juristenkijk op wetgeving: een wetspoliticologisch commentaar, NJB, 1978, p. 833/834

C.J.M Schuyt, Ongeregeld heden, oratie Leiden, Alphen a/d Rijn, 1982

A.Seidman, R.B. Seidman, N. Abeyesekere, Legislative drafting for democratic social change, London, The Hague, Boston, 2001

I.Th.M. Snellen, Boeiend en geboeid, oratie Tilburg, Alphen a/d Rijn, 1987

A. de Swaan, Kwaliteit is klasse, Amsterdam, 1986

S.R. Stoter, N.J.H. Huls, Onderhandelend wetgeven: een proces van geven en nemen, Den Haag, 2003

Strijdige regels in de praktijk, EZ, 2003

G.J. Veerman, De paradox van de wetsevaluatie, Justitiële Verkenningen, 1991-5, p. 8-31

G.J. Veerman, Het meesterschap van de wetgevingsjurist, Den Haag, 2001

L.F.M. Verhey, De zwoegers uit het vooronder, oratie UM, Deventer, 2001

I.C. van der Vlies, De zachte kern van wetgeving, Justitiële Verkenningen, 1991-5, p. 32- 49

W. Voermans, P. Eijlander, R. van Gestel, I. de Leeuw, A. de Moor-van Vugt, 
S. Prechal, Kwaliteit, uitvoerbaarheid en handhaafbaarheid- een onderzoek naar de kwaliteit van EG-regels en de gevolgen daarvan voor de uitvoering en handhaving binnen Nederland, KUB, december 2000

W. Voermans, De Nederlandse wetgever in de communautaire toekomst, preadvies VWW, 2004

M.L. Vos, K. van Doorn, Empowerment- Over laten en doen, Delft, 2004

E.C. de Vos e.a., Evaluatie Wet op de medische keuringen, Den Haag, ZON MW, 2001

M. Wagenaar, Kwaliteit wetgeving stiefkind politiek, RegelMaat, 1999-6, p. $401-413$

E.L.H. de Wilde, Gebrekkige Europese regelgeving kent alleen maar verliezers, SEW 11, 2000.

WRR, De toekomst van de nationale rechtsstaat, rapporten aan de regering, nr. 63, Den Haag, 2002

Zorgonderzoek Nederland, Evaluatie Wet op het bevolkingsonderzoek, Den Haag, 2000 
